\title{
A Trial of Terylene Overalls for Lead-Acid Electric Accumulator Pasters
}

\author{
M. K. WILLIAMS, JOAN WALFORD, and E. KING \\ From the Department of Occupational Health and Applied Physiology, London School of Hygiene and Tropical \\ Medicine, Keppel St., London, W.C.I and the Department of Occupational Health, University of Manchester
}

A comparison of Terylene and cotton overalls has been made in the lead-acid electric accumulator industry. Six hand pasters wore personal lead-in-air samplers for two weeks. Three of the men wore cotton overalls the first week and Terylene overalls the second; the other three men wore Terylene overalls the first week and cotton overalls the second. The mean lead-in-air concentration in the breathing zone when the men wore Terylene overalls was slightly greater than when they wore cotton overalls but the difference was not statistically significant. Significant differences of lead-in-air concentrations were found between men and between the two weeks but not between days within the weeks. The lead-in-air concentration did not increase during the week. Neither a change to Terylene overalls nor more frequent laundering of overalls should be recommended for pasters in this factory on the basis of this study.

Bloor and Dinsdale (1962) studied dust concentrations in the breathing zones of operatives in the pottery industry both in a casting shop and making earthenware. When Terylene overalls were worn in place of cotton overalls the mean dust concentrations were reduced by $66 \%$ and $34 \%$ respectively.

In the manufacture of lead-acid electric accumulator plates, a paste containing lead oxide powder is pressed into the meshes of a lead grid. Lead oxide dust is produced during this process, especially if paste spillage is allowed to dry (Dreessen, Edwards, Reinhart, Page, Webster, Armstrong, and Sayers, 194I). As it has been suggested that Terylene overalls should be worn by lead workers, the leadin-air concentrations of hand pasters wearing both Terylene and cotton overalls have been investigated.

\section{Method}

In an electric accumulator factory employing I $_{5}$ hand pasters, six, selected by the foreman, wore personal samplers $^{1}$ (Williams, 1967) every working day (Monday to Friday) for two consecutive weeks (Fig. I).

The personal sampler (Fig. 2) consists of a sampling head, worn on the lapel, connected by a plastic tube to the pump unit, worn on the belt. Contaminated air is

${ }^{1}$ Cassella \& Co. (1966).

Received for publication November 22, 1967. drawn through a glass-fibre filter-disc held in position by a plastic cap. A flow rate of $21 . / \mathrm{min}$. is indicated by a ball in an internally tapered transparent tube. The pump is driven by a governed motor from rechargeable batteries having sufficient capacity for an eight-hour run. A window in the case exposes an hour-meter. A socket and switch plug are used to start the motor, and the same socket is used for connecting the battery charger, which converts mains voltage A.C. to charging voltage D.C. The charger has an on-off switch and a switch marked $\mathrm{I} 4 \mathrm{H}$ for charging overnight and $64 \mathrm{H}$ for charging over a weekend.

During the first week three of the men wore their usual cotton overalls; the other three men wore Terylene overalls weighing $4 \frac{1}{2} \mathrm{oz} / \mathrm{sq}$. yard, made to the design of Bloor and Dinsdale (I962). All overalls were laundered at the weekend and reissued so that the men who wore cotton the first week wore Terylene the second week and vice versa (Table). A cotton cap, rubber apron, and rubber boots were also worn (The Electric Accumulator Regulations, 1925).

One man pasted two types of plate during the experiment, one of each type on alternate days of the week starting with the same type each Monday. Each of the other men pasted the same type of plate every day. The numbers of plates pasted each day by each man were recorded.

Six personal samplers and six pasting benches were used. During the first week each man was allocated at random a different personal sampler and a different bench each day. This allocation was repeated in the second week. The personal samplers were switched on whenever the men approached their work benches and 


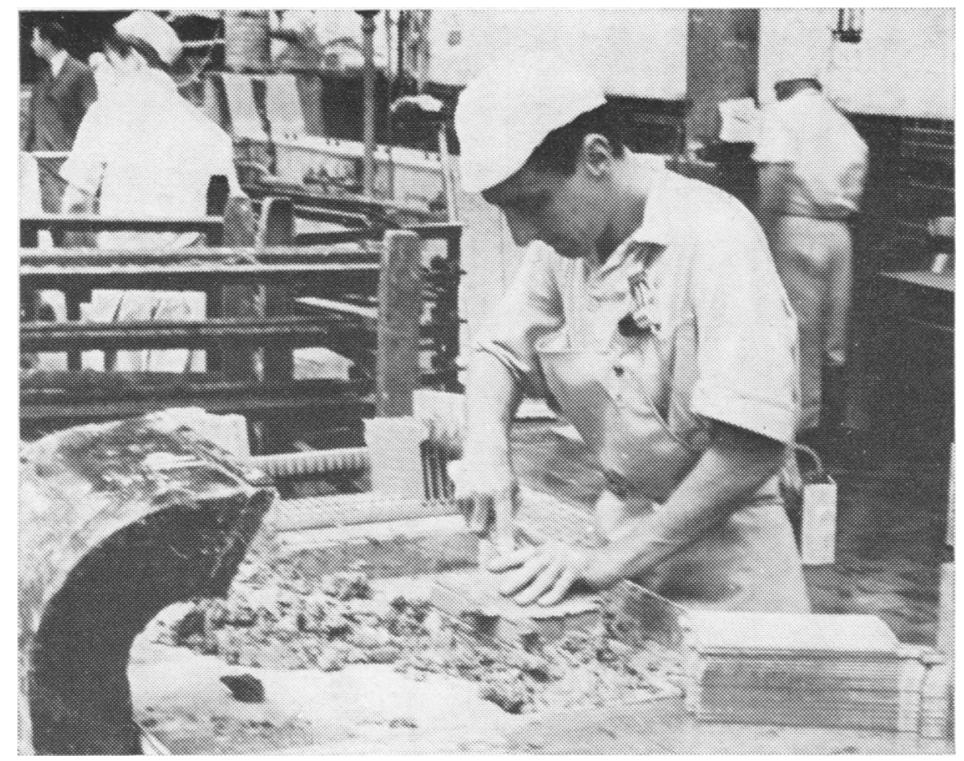

FIG. I. Hand paster wearing personal sampler.

switched off whenever they left them. At the end of the day the personal sampler filter-discs were renewed, the hour meters read, the speeds timed, and the flows checked with a calibrating device and adjusted, where necessary, to lie within the range $2 \cdot 0 \pm 0.21 . / \mathrm{min}$.
(Williams, 1967). The samplers were recharged overnight. The amount of lead on each filter-disc was estimated polarographically and the mean concentration of lead-in-air was calculated from the hour meter readings for a flow of 21 ./minute. 
TABLE

LEAD-IN-AIR ConCentrations (MG./M. ${ }^{3}$ )

\begin{tabular}{|c|c|c|c|c|c|c|c|c|c|c|c|c|c|}
\hline \multirow[t]{2}{*}{ Man } & \multicolumn{5}{|c|}{ First Week } & \multirow[t]{2}{*}{ Mean } & \multicolumn{5}{|c|}{ Second Week } & \multirow[t]{2}{*}{ Mean } & \multirow{2}{*}{$\begin{array}{c}\text { Grand } \\
\text { Mean }\end{array}$} \\
\hline & $M$ & $T u$ & $W$ & $T h$ & $F$ & & $M$ & $T u$ & $W$ & $T h$ & $F$ & & \\
\hline & \multicolumn{5}{|c|}{ Cotton } & & \multicolumn{5}{|c|}{ Terylene } & \multirow{3}{*}{$\begin{array}{l}0.173 \\
0.132\end{array}$} & \multirow{4}{*}{$\begin{array}{l}0.195 \\
0.157 \\
0.207\end{array}$} \\
\hline I & 0.265 & 0.228 & 0.183 & 0.171 & 0.244 & 0.218 & 0.157 & 0.127 & $0.190^{\star}$ & 0.152 & 0.237 & & \\
\hline 2 & 0.172 & 0.219 & 0.115 & 0.212 & 0.194 & 0.182 & $0.153 \dagger$ & 0.121 & 0.112 & 0.1 II & 0.163 & & \\
\hline \multirow[t]{2}{*}{3} & 0.348 & 0.258 & $0.186^{\star}$ & 0.174 & 0.146 & 0.222 & 0.190 & $0.27 I$ & 0.223 & $0.160^{\star}$ & 0.116 & 0.192 & \\
\hline & \multicolumn{5}{|c|}{ Terylene } & & \multicolumn{5}{|c|}{ Cotton } & \multirow{4}{*}{$\begin{array}{l}0.139 \\
0.208 \\
0.295\end{array}$} & \multirow{4}{*}{$\begin{array}{l}0.154 \\
0.231 \\
0.436\end{array}$} \\
\hline 4 & 0.144 & 0.329 & 0.097 & 0.152 & $0.123^{\star}$ & 0.169 & 0.158 & 0.147 & 0.105 & 0.125 & 0.158 & & \\
\hline 5 & 0.226 & 0.252 & 0.128 & 0.315 & 0.354 & 0.255 & 0.127 & 0.256 & 0.248 & 0.206 & $(0.201)$ & & \\
\hline 6 & 0.785 & 0.731 & 0.259 & $0.466^{\star}$ & 0.644 & 0.577 & 0.393 & 0.352 & 0.347 & 0.122 & 0.263 & & \\
\hline Mean & 0.323 & 0.336 & 0.161 & 0.248 & 0.284 & 0.271 & $0 \cdot 196$ & 0.212 & 0.204 & 0.146 & 0.190 & 0.190 & 0.230 \\
\hline
\end{tabular}

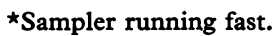

$\dagger$ Based on mean daily time.

( )Estimate of missing value.

\section{Results}

The Table shows the lead-in-air concentrations obtained. On five occasions the hour meter speeds and flow rates of two samplers were found to be high following the overnight charge, perhaps because the battery voltage was low during calibration the previous evening. For the purpose of the calculations it was assumed that the hour meter speed and flow rate were increased proportionately. One of these two samplers was replaced by a spare at the end of the first week. The other failed to operate on the last day and the readings on that day were lost. An estimate of the missing lead-in-air concentration was made by calculating the value that would minimize the error variance of the data.

One of the hour meter readings was rejected as the man had forgotten to switch off his sampler at dinner-break. The reading used was the mean of the other nine readings from the same man.

The number of plates pasted by each man was almost constant from day to day.

The mean lead-in-air concentration when the men wore Terylene overalls was $0.250 \mathrm{mg} . / \mathrm{m}^{3}{ }^{32}$ compared with 0.2 I I mg. $/ \mathrm{m}^{3}$ when they wore cotton overalls. An analysis of variance showed the difference $(17 \%$ of the mean) was not statistically significant at the 0.05 level. The experimental

\footnotetext{
2It may be noted that the T.L.V. of $0.20 \mathrm{mg} . / \mathrm{m} .{ }^{3}$ using static samplers is based on a 'normal workday' (American Conference of Governmental Industrial Hygienists, I965). The mean daily hour meter time was about $5 \frac{1}{2}$ hours. If the 'normal workday' is taken as eight hours, and no other lead exposure occurred, the lead-in-air concentration obtained with personal samplers for Terylene overalls, adjusted to the 'normal workday', is $0.17 \mathrm{mg} . / \mathrm{m}^{3}$.
}

sensitivity was such that a difference in mean lead-in-air concentration between Terylene and cotton of $18 \%$ would have been significant at the 0.05 level. There were, however, statistically significant differences of lead-in-air concentrations between men and between the two weeks $(P<0.001)$ but not between days within the weeks.

\section{Discussion}

Applicants for employment as pasters in this factory were selected, both by personnel and medical officers, for smart appearance and personal cleanliness. Time is allowed for sluicing down rubber aprons at the bench, and supervisors maintain a high standard of cleanliness. This may account for the absence of any observed benefit from Terylene overalls.

Dinsdale (1963) found that replacing the dirty cotton overalls of pottery workers by clean ones reduced the dust concentration in the breathing zone by $50 \%$. The lead pasters' overalls are laundered once a week. The absence in the present study of statistically significant differences between the days within each week, with no indication of an increase in lead-in-air during the week, suggests that no reduction of the lead exposure of these hand pasters would be obtained by laundering more frequently.

Large differences in lead-in-air concentrations between men doing similar jobs are of interest. Such differences have also been observed in another survey, to be published.

Reasons for the differences between weeks (every man had a lower mean reading during the second week) are also of interest but are not known. 
It was concluded that in this factory, where there is a high standard of cleanliness, no change to Terylene overalls should be recommended, and laundering overalls once a week is sufficiently frequent.

We are very grateful to the six men who took part in the survey, to Mr. J. Hay for assistance with the personal samplers, and to Dr. D. Malcolm and the Directors of The Electric Power Storage Co. Ltd. for permission to undertake the investigation.

\section{REFERENCES}

American Conference of Governmental Industrial Hygienists. (1965). Threshold Limit Values for 1965. A.C.G.I.H., Ior4 Broadway, Cincinnati, Ohio.
Bloor, W. A., and Dinsdale, A. (1962). Protective clothing as a factor in the dust hazard of potters. Brit. $\mathcal{F}$. industr. Med., 19, 229.

Casella \& Co. (1966). Personal Air Sampler-Leaflet 930/5/AR. C. F. Casella and Co. Ltd., Regent House, Britannia Walk, London, N.I.

Dinsdale, A. (1963). Design and material of protective clothing for pottery workers. D.S.I.R. Symposium, Mineral Dust in Industry, Stoke-on-Trent, $196 \mathrm{I}$, p. 108. H.M.S.O., London.

Dreessen, W. C., Edwards, T. I., Reinhart, W. H., Page, R. T., Webster, S. H., Armstrong, D. W., and Sayers, R. R. (1941). The Control of the Lead Hazard in the Storage Battery Industry. United States Public Health Service, Public Health Bulletin No. 262.

Electric Accumulator Regulations. (1925). Statutory Rules and Orders. No. 28, H.M.S.O., London.

Williams, M. K. (1967). The measurement of lead absorption. Thesis submitted for the degree of Doctor of Medicine in the University of Oxford. 